\title{
Determinants and Working Conditions of Child Labour: A Case Study of Children Working at Automobiles Workshop at Khyber Pakhtunkhwa (KP), Pakistan
}

Muhammad Jehangir Khan, Khuram Nawaz Sadozai, Karim Khan, Fida Muhammad Khan, Mubasher Rehman Khattak and Haider Ali* Faculty of Rural Social Science, Institute of Development Studies, The University of Agriculture, Peshawar, Pakistan

\begin{abstract}
This study has tried to inspect the determinants and working conditions of child labour in automobile workshops of Tehkal market, Peshawar (KP). Detailed descriptive analysis and multivariate analysis is undertaken to analyze the data and report findings. The results depicts that child labour in the area is a multifaceted phenomenon. Most of the children leave their schools to learn working skills for future employment security. Majority of the sampled children contribute more than 60 percent to family's income. Most of the children has father alive and live in rental houses with their parents. More than half of the children report physical health and drug addiction problem of their fathers. The data further divulge that only 1 percent of the children are the sole bread earners of their families. The working condition of the automobile workshops is hazardous with no basic facilities. Nearly 85 percent of the children reported punishment at work place by underpaying their salaries followed by physical abuse. The multivariate analysis illustrates that low household income, literacy level, profession, household size, and paternal physical health are the major factors of child labour. The coefficients of all the variables are significant and having correct theoretical signs predicting that these variables greatly influences the wage per hour of the child.
\end{abstract}

Keywords: Child labour; Working conditions; Automobiles workshop; Case study; Khyber Pakhtunkhwa

\section{Introduction}

Child labour is an important issue among professional, academic and media [1]. This is a universal problem throughout the world and is worth to investigate [2]. Children have contributed to the household economy in one form or another by means of participating in different activities. From an early age children contribute in earning income at the cost of their own livelihood and deprived of basic opportunities for education, leisure, recreational and intellectual development [3]. The International Labour Organization (ILO), defined child labour as harmful for all children below age of 18 in the labour market or their own household. Defining the term 'child' could be compound by many factors like racial and climatic factors related to physical and mental maturity, social norms and practices, socio-economic conditions, educational system and the legal context of the country. The economic activity in which the child is involved has either positive or negative impacts depending upon the age, physical and environmental condition of work [4].

There is common perception that if a child is engaged in economic activity is considered as child labour whereas if child is not being paid comes under child work [5]. But in contrary according to (ILO) if child is economically active without any physical and mental stress is child work while violation of international labour laws refers to child labour. Asia is economically active region of the world and it has the greatest incidence of child labour [6]. Asia and Africa together are responsible for producing ninety percent of total child labour force. Around sixty percent of the children of the world are working under unfavorable conditions. In India 44 million children are working while 12 million children are working in Nigeria [7]. According to 1973 constitution of Pakistan "no child under the age of 14 shall be employed in hazardous jobs [6]. Federal Bureau of Statistics conducted national survey of child labour with collaboration of ILO in 1996 and find that 40 million children age 5 to 14 were economically active among which 73 percent were boys while 27 percent were girls. According to the survey majority of children were working in agriculture sector. Around 33 percent of children never attended school, 46 percent of children had to work more than 35 hours per week. The report concluded that low socio-economic background; poor education system, uneducated household heads and large family size were pushing children into labour [8]. Pakistan has grave problem of child labour and main reasons could be weak socioeconomic and political instability. Thousands of the children have to quit education at intial level to meet the basic necessities of life [9].

The future of every nation is dependent on children skills and their capabilities. The study is more related to the explanation of present child labour in Tehkal area (KPK). It also focuses on the reasons which bring children in to labour. The findings of the study will helpful for the local government to understand the worst condition of child labour. The recommendations if implemented properly can minimize the consequences of worst form of child labour (WFCL). Child labour is the employment of children working between 7 to 18 years on wages or when used for inappropriate or dangerous jobs. According to Keyemuddin and Kayum automobiles workshop is a type of small industry for repairing and maintaining vehicles and Khan categorized workshops into two type's i.e. heavy vehicle workshops and light vehicle workshops $[5,10]$. Trucks buses and tractors are repaired at heavy vehicle workshops while rickshaws, cars and motorcycles are repaired at light vehicle workshops. The study will investigate the determinants

*Corresponding author: Haider Ali, Faculty of Rural Social Science, Institute of Development Studies, The University of Agriculture, Peshawar, Pakistan, Tel+923339350722; E-mail: haiderkpk59@gmail.com

Received January 22, 2018; Accepted February 13, 2018; Published February 19, 2018

Citation: Khan MJ, Sadozai KN, Khan K, Khan FM, Khattak MR, et al. (2018) Determinants and Working Conditions of Child Labour: A Case Study of Children Working at Automobiles Workshop at Khyber Pakhtunkhwa (KP), Pakistan. Arts Social Sci J 9: 332. doi: 10.4172/2151-6200.1000332

Copyright: $\odot 2018$ Khan MJ, et al. This is an open-access article distributed under the terms of the Creative Commons Attribution License, which permits unrestricted use, distribution, and reproduction in any medium, provided the original author and source are credited. 
of child labour working in light automobiles workshops. The objectives of the study are as under:

$>$ To evaluate the child characteristics of child working in automobile workshop,

To explore the parental factors leading to child labour in study area,

To examine the household characteristics that forced child to go to work.

\section{Review of Related Literature}

Child labor has many determinants ranging at first hand from demographic variables to working condition along with parental and socio-economic determinants. The general perception that child labour is embedded in poverty need not be fit in every context and cultures rather could be viewed as a complex phenomenon which required simplification. The association between the underlying bases of child labour and the surrounding exploitation is not that much simple as the literature demonstrate. An additional effort is needed to determine the root cause of the issue so that to carry out specific measures, as generalization of the issue mean we are avoiding different measures regarding different fundamental causes.

In developing countries child labour and high dropout from school are major issues and poverty being the key factor that forces children to work [11]. Panigrahi conducted a study in rural Orissa (India) and founded that lack of interest in education, unemployment; poor economic status, illiteracy and large family size are the contributing factor of child labour [3]. Emerson and Knabb explained not only the poverty is responsible but child labour is considered as family occupation and transmitted through generation [12]. He feared that by introducing anti child labour policies and compulsory education laws can increase the poverty and income inequality within a society making the condition more worst and eventually can appreciate child labour.

Ahmad conducted a study at Aligarh city to depict the socioeconomic problems of working children by taking 360 sample sizes [13]. The study revealed that most of the parents were either unemployed or had no permanent occupation. It was found that 25 percent of children were in labour because of poverty, 17 percent of children were working because of the parental pressure, 15 percent were uninterested in attending schools, 11 percent had to support family and 6 percent were only source of family income. Siddiqi conducted a case study in Lahore Pakistan where 40 percent of population were living below poverty line and founded that large family size was one of the contributing factor [14]. Ali conducted a study in district Swabi and discussed economic factors which were responsible for child labour [6]. The study was based on a sample of 225 respondents who were interviewed to examine the determinants of child labour in the locale and found 37 percent working children reported that their parents were labours having no good job, 70 percent of children acknowledged that the family income was too low that they had to work for family support. It was also found that half of the respondent's parents were having income less than PKR 4,000 per month. It can be inferred from the data that parents having low income sent their children to labour.

Dash determined the contributing factor of child labour at Delhi [15]. The study was descriptive in nature in which 120 child labours and 40 parents were selected for interview and found that 62 percent children were working because of parental compulsion on them as well as they had to support the family bearing poor economic background. The same results were also determined by Khan in 2007 while conducting a study in Bannu city of KPK Pakistan and maintain that 20 percent of the children were taken as sample and it was pointed that household income was inversely related to prevalence of child labour. It was also examined that majority of the parents were illiterate and had income lower than PKR 3500 per month. Thus, it is evident from the study that children had to take responsibility by contributing in family income. Grootaert and Patrinos emphasized that parental unemployment pressurized the child to go for work rather than school as well as Parental education directly influence child labour rate [16]. Ampomah conducted study to analyze the child labour condition in areas of Abokobi and Madina east districts of Ghana which interviewed 50 children, 50 parents and three government officials [17]. The study examined the working condition of children, programmers and policies as well as problems faced by these programs and primarily conclude that 60 percent of respondents regarded poverty as the main cause. In addition, majority of parents were unemployed, 70 percent were involved in petty training, 79 percent were getting income from low scale business and 42 percent of parents were uneducated. Thus, the children having low socio-economic status were forced by parents to provide financial assistance.

According to Siddiqi and Patrinos child labour is a problem faced by developing countries throughout the world. Parental decision plays vital role in promoting child labour [18]. Children contribute more in reducing the financial burden as compared to the children of developed nations. School enrollment being a substitute of child labour and parents select the option of schooling and work choice based on utility. The provision of free text books and facilities at primary level can increase the school enrollment. By providing different incentives at the early stage can reduce child labour. Education can improve the skills and opportunities of masses by means of governmental incentive program.

The aforementioned empirical literature shows that factors like socio-economic, cultural aspects, family size, and parental education among others has diverse and mixed effect on child labour. Almost, all of the studies conducted in Pakistan so far examine either economic factors of child labour or socio-political factors. This study intends to examine the three characteristics of child labour including parental, household and child own characteristics. Furthermore, the study chooses the area which is more vulnerable to child labour. Therefore, this study is an extension of the available literature in the direction of examining the three characteristics of child labour. The study also shed light on the working condition of children working in automobile industry, district Peshawar.

\section{Material and Methods}

The study is descriptive cum analytical. The collection of primary data is an effort in the form of semi-structured interview conducted. Specifically, the study is structured analytically, present data collection and sampling technique along with the method of research utilized in the data collection process. Tehkal is located in the center of Peshawar; it is one of the main commercial areas of Peshawar having automobiles workshop located on the main roads as well as in the streets. The study mainly focuses on children aged 7-18 working in automobile workshop. There are about 300 automobiles workshops in which most of the work is done by the children; mainly in the car denting, car paint, mechanical and electrical sections. In 300 automobiles workshop 1500 children aged 7-18 were working constitute the population of data. Out of 300 automobile workshops 150 automobiles were randomly taken. From 
Citation: Khan MJ, Sadozai KN, Khan K, Khan FM, Khattak MR, et al. (2018) Determinants and Working Conditions of Child Labour: A Case Study of Children Working at Automobiles Workshop at Khyber Pakhtunkhwa (KP), Pakistan. Arts Social Sci J 9: 332. doi: 10.4172/21516200.1000332

Page 3 of 7

each automobile workshop two children were randomly selected. So, 300 children constitute the sample size of the study.

Data was collected by means of semi-structured interview; comprised of four sections. The first section covered child characteristics consisting age, education, birth order, percentage contribution to family income, reasons of leaving school and work experience. The second section having questions regarding parent's occupation, education, housing, physical fitness, drug addiction and per month income. The third section inquired household characteristics i.e. earning family members, family income per month, family size, occupational family structure, sibling education, sibling disability and the number of children involved in labour. The last section had questions pertaining to working conditions i.e. total working hours per day availability of basic facilities, duration of mid-day break, type of punishment and different type of injuries.

The proposed study is intended to provide first the descriptive analysis of the study in order to examine the determinants of child labour i.e. child own characteristics, father characteristics and household characteristics. For further evidence on the subject issue the study intended to use the multiple regression technique. The study regressed the working hours per day of the children on variables including birth order, work experience, household head occupation, household head education, physical health, family income per month, number of children involved in labour, wage per hour and family size. The relationship between working hours per day of children and independent variables are represented as follows.

$W H=\beta_{0}+\beta_{1} B O+\beta_{2} \quad W E+\beta_{3} H H O+\beta_{4} H H E+\beta_{5} P H+\beta_{6} F I P M+\beta_{7}$ $N C I L+\beta_{8} F S+\beta_{9} W P H+\varepsilon_{\mathrm{i}}$

Where $\mathrm{WH}=$ working hours per day

$\mathrm{BO}=$ Birth order of the children

$\mathrm{WE}=$ work experience of the children

$\mathrm{HHO}=$ Household Head Occupation

HHE=Household Head Education

$\mathrm{PH}=$ physical health of the fathers

FIPM=income of the family per month

$\mathrm{NCIL}=$ number of children involved in labour

FS=size of the family

$\mathrm{WPH}=$ wage per hour of the children

While $\varepsilon_{\mathrm{i}}$ is the error term capturing the average effect of omitted variables.

We cannot enter directly the categorical independent variables into regression model because it cannot be meaningfully interpreted and we therefore required an alternative way to deal with such issue. One alternative way is the dummy coding which has the characteristic to transform a $\mathrm{k}$ level categorical variable into $\mathrm{k}-1$ level. We transform the categorical variables into dichotomous variables by following the dummy coding technique. The dummy coding for one categorical variable (i.e. birth order) are presented here. We have four levels in birth order i.e. youngest, second to fifth, third to sixth and eldest which could be dummy coded into three variables i.e. youngest, second to fifth and third to sixth. The way in which the dummy is coded is presented (Appendix 1).

\section{Results and Discussion}

\section{Descriptive analysis}

The descriptive analysis is carried out to achieve the objective of the study along with to examine the demographic and socio-economic characteristics of the sample in the study area. To describe, categorize and summarize the data analytically in a comprehensive form, descriptive analysis is the most widely used technique Nachmias and Nachmias [19-23]. Percentages and classification of data is the center of descriptive analysis.

Table 1 reveals that highest percentage of children that work in automobile workshop were between 11-14 years of age, followed by those children whose ages are in the range of 9-10 and 15-17 (25

\begin{tabular}{|c|c|c|c|}
\hline Variable & Frequency & Percent & Cumulative percent \\
\hline \multicolumn{4}{|l|}{ Age } \\
\hline $7-8$ & 24 & 8.0 & 8.0 \\
\hline $9-10$ & 74 & 25.0 & 33.0 \\
\hline $11-14$ & 128 & 43.0 & 75.3 \\
\hline $15-17$ & 74 & 25.0 & 100 \\
\hline Total & 300 & 100.0 & \\
\hline \multicolumn{4}{|l|}{ Level of education } \\
\hline Illiterate & 85 & 28.3 & 28.3 \\
\hline Primary & 99 & 33.9 & 61.3 \\
\hline Middle & 17 & 6.0 & 67.0 \\
\hline Matric and above & 99 & 32.1 & 100 \\
\hline Total & 300 & 100 & \\
\hline \multicolumn{4}{|l|}{ Birth order } \\
\hline Youngest & 7 & 2.3 & 2.3 \\
\hline Second to fifth & 136 & 45.3 & 48.0 \\
\hline Third to sixth & 20 & 7.0 & 55.0 \\
\hline Eldest & 137 & 45.7 & 100 \\
\hline Total & 300 & 100.0 & \\
\hline \multicolumn{4}{|l|}{ Work experience } \\
\hline Up to 1 year & 61 & 20.3 & 20.3 \\
\hline $1-4$ years & 93 & 31.0 & 51.3 \\
\hline 4-7 years & 54 & 18.0 & 69.3 \\
\hline $7-10$ years & 92 & 31.0 & 100 \\
\hline Total & 300 & 100 & \\
\hline \multicolumn{4}{|l|}{ Income per month (PKR) } \\
\hline Up to 1500 & 40 & 13.3 & 13.3 \\
\hline $1500-3000$ & 73 & 24.3 & 38.0 \\
\hline $3000-5000$ & 123 & 41.0 & 79.0 \\
\hline 5000 and above & 64 & 21.3 & 100 \\
\hline Total & 300 & 100 & \\
\hline \multicolumn{4}{|c|}{ Percentage contribution to family income } \\
\hline up to $20 \%$ & 17 & 6.0 & 6.0 \\
\hline $20-40 \%$ & 26 & 9.0 & 14.3 \\
\hline $40-60 \%$ & 175 & 58.3 & 73.0 \\
\hline $60 \%$ and above & 82 & 27.3 & 100 \\
\hline Total & 300 & 100 & \\
\hline \multicolumn{4}{|l|}{ Reason of leaving school } \\
\hline Lack of interest & 25 & 8.3 & 8.3 \\
\hline $\begin{array}{l}\text { Poor Economic } \\
\text { Background }\end{array}$ & 130 & 43.3 & 51.6 \\
\hline $\begin{array}{l}\text { Future employment } \\
\text { Security }\end{array}$ & 94 & 31.3 & 83.0 \\
\hline Law and order condition & 51 & 17.0 & 100 \\
\hline Total & 300 & 100 & \\
\hline
\end{tabular}

Source: Authors own calculation.

Table 1: Distribution of respondents with regards to child characteristics. 
Citation: Khan MJ, Sadozai KN, Khan K, Khan FM, Khattak MR, et al. (2018) Determinants and Working Conditions of Child Labour: A Case Study of Children Working at Automobiles Workshop at Khyber Pakhtunkhwa (KP), Pakistan. Arts Social Sci J 9: 332. doi: 10.4172/21516200.1000332

Page 4 of 7

percent each). About 28 percent of children working in automobile workshops have no education, 34 percent have primary education, whereas matric and above is the second highest category (32 percent). The eldest children constitute the largest friction of the sample followed by the second youngest. Children who have 1 to 4 years of working experience are 31 percent of the sample [24-27]. Similarly, another 31 percent of the total sample children have 7 to 10 years of experience. About 43.3 percent of the children leaves school due to poor economic background in order to support their families. The second largest percentage (31.3 percent) of the sampled children leaved school due to future employment security. Children whose earnings are inbetween 3000 to 5000 has the largest percentage (41 percent), followed by earnings group of 1500 to 3000 . Percentage contribution to family income is conceivably the most significant part of child labour story in the locale, as about 27 percent of the sampled children contribute more than 60 percent to family income. Another 58 percent of the sampled children contribute nearly 40-60 percent to family income. This shows that these children are the sole bread earners of their families, ensuring their family survival. The data further shows that being the elder the child the more responsible he is for managing family affairs.

Table 2 distributes children by their parental characteristics. Most of the children ( 88 percent) has father alive. Similarly, most of the children live in rental houses (39.3 percent) with their parents. More than half (69 percent)of the sampled children fathers are not physically fit confirming that physical health is one of the significant determinants of child labour. Further, the data shown that 66 percent of the sampled children fathers are drug addicted.

Table 3 presents household characteristics of the laborer children. Majority of the labourer children are from families having 2-4 or 5-7 bread earners ( 49 percent each) [28-30]. Those families where children are the sole bread earners are only 1 percent. Most of the children have family income in the range of $10-15$ or 20 thousand and above (33 percent each). Child labor is higher in families having larger household sizes. Most of the household heads are wage earners and or unemployed. More than half of the sampled children's fathers are illiterate, which may be the major factor that pushes children to work in automobile workshop.

Elder children often choose work rather than go to school to support their sibling education. About 47 percent of the children respond that

\begin{tabular}{|c|c|c|c|}
\hline Correlates/variables & Frequency & Percentage & $\begin{array}{l}\text { Cumulative } \\
\text { Percentage }\end{array}$ \\
\hline \multicolumn{4}{|l|}{ Is your father alive } \\
\hline Yes & 264 & 88.0 & 88.0 \\
\hline No & 36 & 12.0 & 100 \\
\hline Total & 300 & 100 & \\
\hline \multicolumn{4}{|l|}{ Where do you live? } \\
\hline Rental house & 118 & 39.3 & 39.3 \\
\hline Own house & 87 & 29.0 & 68.3 \\
\hline Relatives & 8 & 3.0 & 71.0 \\
\hline Others & 87 & 29 & 100 \\
\hline Total & 300 & 100 & \\
\hline \multicolumn{4}{|c|}{ Does father is Physically fit? } \\
\hline Yes & 93 & 31.0 & 31 \\
\hline No & 207 & 69.0 & 100 \\
\hline \multicolumn{4}{|c|}{ Does father is drug addicted? } \\
\hline Yes & 198 & 66.0 & 66 \\
\hline No & 102 & 34.0 & 100 \\
\hline
\end{tabular}

Source: Authors own calculation.

Table 2: Distribution of respondents with regards to their paternal characteristics.

\begin{tabular}{|c|c|c|c|}
\hline Variables & Frequency & Percent & Cumulative Percent \\
\hline \multicolumn{4}{|c|}{ Earning family members } \\
\hline Nil & 3 & 1.0 & 1.0 \\
\hline $2-4$ & 147 & 49.0 & 50.0 \\
\hline $5-7$ & 146 & 49.0 & 99.0 \\
\hline 8-above & 4 & 1.3 & 100 \\
\hline Total & 300 & 100 & \\
\hline \multicolumn{4}{|c|}{ Family income per month (PKR) } \\
\hline $0-10000$ & 13 & 4.3 & 4.3 \\
\hline $10000-15000$ & 99 & 33.0 & 37.3 \\
\hline $15000-20000$ & 90 & 30.0 & 67.3 \\
\hline 20000 and above & 98 & 33.0 & 100.0 \\
\hline Total & 300 & 100 & \\
\hline \multicolumn{4}{|l|}{ Family size } \\
\hline $2-4$ & 23 & 8.0 & 8.0 \\
\hline $5-7$ & 95 & 30.0 & 40.0 \\
\hline 8-10 & 86 & 29.0 & 68.3 \\
\hline 10-above & 96 & 32.0 & 100 \\
\hline Total & 300 & 100 & \\
\hline \multicolumn{4}{|l|}{ Head occupation } \\
\hline $\begin{array}{l}\text { Government } \\
\text { employee }\end{array}$ & 67 & 22.3 & 22.3 \\
\hline wage earner & 102 & 34.0 & 56.3 \\
\hline self employed & 30 & 10.0 & 66.3 \\
\hline unemployed & 101 & 34.0 & 100 \\
\hline Total & 300 & 100 & \\
\hline \multicolumn{4}{|c|}{ Household head education } \\
\hline illiterate & 183 & 61.0 & 61.0 \\
\hline primary & 43 & 14.3 & 75.3 \\
\hline middle & 32 & 11.0 & 86.0 \\
\hline matric and above & 42 & 14.0 & 100 \\
\hline Total & 300 & 100 & \\
\hline \multicolumn{4}{|l|}{ Sibling education } \\
\hline Pre-school & 60 & 20.0 & 47.0 \\
\hline Primary & 141 & 47.0 & 67.0 \\
\hline Secondary & 34 & 11.3 & 78.0 \\
\hline Never went to school & 65 & 22.0 & 100 \\
\hline \multicolumn{4}{|l|}{ Sibling disability } \\
\hline Physical impairment & 172 & 57.33 & 57.3 \\
\hline Spinal Cord Disability & 45 & 15.0 & 72.3 \\
\hline Brain disability & 61 & 20.3 & 92.6 \\
\hline Learning disabilities & 22 & 7.3 & 100 \\
\hline \multicolumn{4}{|c|}{ Number of children involved in labour } \\
\hline Only one child work & 122 & 40.6 & 40.6 \\
\hline Two children work & 93 & 31.0 & 71.6 \\
\hline Three children work & 65 & 21.6 & 93.2 \\
\hline Four children work & 20 & 6.6 & 100 \\
\hline
\end{tabular}

Source: Authors own calculation.

Table 3: Distribution of Respondents with Regards to their Household Characteristics.

their sibling education is primary. Nearly 57 percent of the sibling have disability (physically impaired). About 41 percent of children respond that only one child involved in labor.

Table 4 tried to report the working conditions of the children in automobile workshops. About 61 percent of the children responds that there are no basic facilities (water, electric fan, heater, first aid) available at their work place. Nearly 85 percent of the children reported punishment at work place. Most of the children are punished by underpaying their salaries ( 55 percent) followed by physical abuse (30 percent) [31-33]. About 77 percent of the children respond that 
Citation: Khan MJ, Sadozai KN, Khan K, Khan FM, Khattak MR, et al. (2018) Determinants and Working Conditions of Child Labour: A Case Study of Children Working at Automobiles Workshop at Khyber Pakhtunkhwa (KP), Pakistan. Arts Social Sci J 9: 332. doi: 10.4172/21516200.1000332

Page 5 of 7

\begin{tabular}{|c|c|c|c|}
\hline Variables & Frequency & Percent & Cumulative Percent \\
\hline \multicolumn{4}{|c|}{ Basic facilities at workshop (water, electric fan, heater, first aid) } \\
\hline Yes & 118 & 39.3 & 39.3 \\
\hline No & 182 & 60.6 & 100.0 \\
\hline Total & 300 & 100.0 & - \\
\hline \multicolumn{4}{|c|}{ Are you punished at work place } \\
\hline Yes & 254 & 85.0 & 85.0 \\
\hline No & 46 & 15.3 & 100.0 \\
\hline Total & 300 & 100.0 & - \\
\hline \multicolumn{4}{|l|}{ Type of punishment } \\
\hline Physical Abuse & 91 & 30.3 & 30.3 \\
\hline Verbal Abuse & 28 & 9.3 & 40.0 \\
\hline Salary Deduction & 165 & 55.0 & 95.0 \\
\hline Extra Work & 16 & 5.3 & 100.0 \\
\hline Total & 300 & 100.0 & - \\
\hline \multicolumn{4}{|c|}{ Working condition hazardous or Dangerous? } \\
\hline Yes & 232 & 77.3 & 77.3 \\
\hline No & 68 & 22.6 & 100.0 \\
\hline Total & 300 & 100.0 & - \\
\hline \multicolumn{4}{|c|}{ Injuries faced during work } \\
\hline Cuts and Burns & 76 & 25.3 & 25.3 \\
\hline Orthopaedics Injuries & 170 & 57.0 & 82.0 \\
\hline Skin Allergies & 32 & 11.0 & 93.0 \\
\hline ENT infection & 22 & 7.3 & 100.0 \\
\hline Total & 300 & 100.0 & - \\
\hline \multicolumn{4}{|c|}{ Protective tools available? } \\
\hline Yes & 5 & 1.6 & 1.6 \\
\hline No & 295 & 98.4 & 100 \\
\hline Total & 300 & 100.0 & - \\
\hline
\end{tabular}

Source: Author's own calculation.

Table 4: Distribution of respondents with regards to their working conditions.

their working conditions are hazardous/dangerous to their health. Most of the children (57 percent) faced orthopedics injuries during work followed by cuts and burns ( 25 percent). Some reported eye or ear infections. Only 5 percent of the children reported protective tools available at the workplace.

\section{Regression results}

We estimate eqn. (1) through ordinary least square (OLS) regression. The results of which is shown in Table 5, we report the coefficients of the model and the probability value (p-value). Table 5 demonstrate the results of the independent variables, most of the coefficients are significant (all the p-values are equal to or less than 5 percent) having correct theoretical signs. The positive sign on the coefficients of age and its magnitude tell us that as compare to base category (age group 7-8) the upper age groups (9-10,11-14 and 15-17) working hours per day are respectively $8.14,4.32$ and 5.71 times greater. Age is positively and significantly related with working hours per day and old child earning more per hour than young child. This is because old children could be more experienced than the young children along with old have the capability to work more than the young. This evidence are further confirmed by the birth order variable where the relatively older in birth order as compare to the youngest are working 7.48 and 8.58 times more hours respectively. One exception is that, that age group of second to fifth are negatively but insignificantly related to working hours per day. For this one justification could be in fact that this group is very close to the youngest age group. More experienced children are considered to be working more hours than the less experienced children and this is what our results also confirm. Children who had experience of 1-4 years are working 3.59 times higher than the base category that is experience up

\begin{tabular}{|c|c|c|}
\hline Variables & Coefficients & P-value \\
\hline \multicolumn{3}{|l|}{ Age $(7-8)^{*}$} \\
\hline Age $(9-10)$ & 8.14 & 0.02 \\
\hline Age (11-14) & 4.32 & 0.001 \\
\hline Age (15-17) & 5.71 & 0.03 \\
\hline \multicolumn{3}{|l|}{ Birth Order (Youngest) ${ }^{*}$} \\
\hline Birth Order(second to fifth) & -3.09 & 0.12 \\
\hline Birth Order (third to sixth) & 7.48 & 0.03 \\
\hline Birth Order (eldest) & 8.58 & 0.04 \\
\hline \multicolumn{3}{|l|}{ Work Experience (up to 1 year)* } \\
\hline Work Experience (1-4) & 3.59 & 0.005 \\
\hline Work Experience (4-7) & 1.61 & 0.020 \\
\hline Work Experience (7-10) & 5.29 & 0.005 \\
\hline \multicolumn{3}{|l|}{ Wage per hour } \\
\hline \multicolumn{3}{|l|}{ Head is government employs* } \\
\hline Headis wage earners & 4.21 & 0.05 \\
\hline Head is self employed & 2.15 & 0.00 \\
\hline Head is unemployed & 7.19 & 0.00 \\
\hline \multicolumn{3}{|l|}{ Head is illiterate* } \\
\hline Head is primary & 5.61 & 0.03 \\
\hline Head is middle & -3.22 & 0.00 \\
\hline Head is matric and above & -7.32 & 0.00 \\
\hline \multicolumn{3}{|l|}{ father is Physically fit* } \\
\hline father is not Physically fit & 9.52 & 0.06 \\
\hline \multicolumn{3}{|l|}{ Family income per month $0-10000^{*}$} \\
\hline Family income per month $10000-15000$ & 3.58 & 0.04 \\
\hline Family income per month $15000-20000$ & -5.04 & 0.03 \\
\hline $\begin{array}{l}\text { Family income per month } 20000 \text { and } \\
\text { above }\end{array}$ & -1.21 & 0.21 \\
\hline \multicolumn{3}{|l|}{ Family Size $2-4^{*}$} \\
\hline Family Size 5-7 & 1.34 & 0.03 \\
\hline Family Size 8-10 & 2.53 & 0.05 \\
\hline Family Size 10 -above & 6.31 & 0.00 \\
\hline \multicolumn{3}{|l|}{ Only one child work* } \\
\hline Two children work & 4.54 & 0.01 \\
\hline Three children work & 1.39 & 0.04 \\
\hline Four children work & 5.55 & 0.15 \\
\hline Constant & 12.22 & 0.003 \\
\hline$R^{2}$ & \multicolumn{2}{|c|}{0.73} \\
\hline F-Statistics & 23.31 & \\
\hline
\end{tabular}

Source: Authors own calculation.

Note: * is the reference category.

Table 5: Regression Results (dependent variable working hours per day)

to only one year. Similarly, those children who had experience of 4-7 and 7-10 years working respectively 1.61 and 5.29 times higher than those who had only one year of experience.

Three variables from parent's and household characteristics can also influence the working hours per day of the children including household head occupation, household head education and physical health of the fathers. The result shows that the working hours per day are 4.21 times higher of those children whose heads are wage earners as compared to whose heads are government employees [34-38]. The working hours of the children whose heads are unemployed are 7 times higher as compare to the reference category. Working hours per day of those children whose heads are relatively more educated are less than those whose heads are less educated. Similarly, children having physically unfit fathers working 9.52 times more than those whose fathers are physically fit.

Those children whose family income are higher work less hours 
Citation: Khan MJ, Sadozai KN, Khan K, Khan FM, Khattak MR, et al. (2018) Determinants and Working Conditions of Child Labour: A Case Study of Children Working at Automobiles Workshop at Khyber Pakhtunkhwa (KP), Pakistan. Arts Social Sci J 9: 332. doi: 10.4172/21516200.1000332

Page 6 of 7

per day as compare to whose children whose family income is less. Similarly, working hours of the children belongs to big family size are higher because they must work to meet the higher needs of their family as compare to who has less family members.

\section{Conclusion}

Child, parent, and household are important aspects of child labour that are investigated in this study. The child own aspects show that majority of the children working in automobile workshops are in the ages of 11-14 years. Most of the children have primary education. Majority of the children are from families having larger household size. Whereas, most of the children in automobile workshops are the eldest in birth order. Similarly, most of the children acquire considerable experience which are likely to help them in future work. Child earnings constitute nearly 60 percent of the total family income. About 58 percent of the children left school due to poor economic background of their families.

Majority of the household heads are uneducated, which pushes their children to work in automobile workshops. Most of the children are from families who lives in rental house and has low income. A greater proportion of the children reported paternal drug addiction or either physically unfit having disability.

The working environment in automobile workshops was generally not satisfactory. Almost 77 percent of the of the children are working in hazardous conditions which lacked basic facilities. Most of the children reported punishment at work place ( 85 percent). About 55 percent of the children are underpaid as a penalty. The unavailability of protective tools results in orthopedics injuries (57 percent) during work; followed by cuts and burns ( 25 percent).

The multivariate analysis shows that old age children are working more hours per day than young age children. The same is the case for birth order and child experience variables. Similarly, children from families whose heads are either unemployed or wage earners and less educated are working more hours per day than households headed by employed and more educated members. Lastly children belong to families having higher income are working less hours per day than lower income families.

The current findings show that child labor is a multifaceted problem. Perhaps the most effective policy is the affordable and accessible education policy as education reduces the time to child work and education enhances human capital, productivity and more income. Raising awareness campaign regarding schooling of victim child along with attention must be diverted of the local government to the said issue to find ways and get rid of this issue on earlier basis.

\section{References}

1. Ray R (2000) Analysis of child labor in Peru and Pakistan: A comparative study. Journal of population economics 13: 3-19.

2. Abdul Hai A, Fatima A, Sadaqat M (2010) Socio-economic conditions of child labor: A case study for the fishing sector on Balochistan coast. International Journal of Social Economics, pp: 316-338.

3. Panigrahi M (2003) Plight of Child Laborers in Rural Orissa Indian Anthropologist 33: 37-51.

4. Herath G, Sharma K (2007) Child Labor in South AsiaAshgate Publishing Ltd. International Labor Organization (ILO).

5. Khan RE (2003) The determinants of child labor: A case study of Pakpattan and Faisalabad (Pakistan)Doctoral dissertation. Department of Economics Bahauddin Zakariya University, Pakistan.
6. Ali G (2010) Economic Factors Responsible for Child Labor (A Case study of District Swabi). Journal of Managerial Sciences, pp: 86-96

7. Rena $P(2009)$ The child labor in developing countries: a challenge to millennium development goals Indus Journal of Management \& Social Sciences 3: 1-8.

8. Zarif T, Aziz-un-Nisa AA (2013) Understanding reasons of child labor in a developing economy: A qualitative study of Karachi Pakistan. Asian Journal of Social Sciences \& Humanities 2: 388-393.

9. Mahmood S, Maann AA, Tabasam N, Niazi SK (2005) Socio-Economic determinants of child labor in automobile and Engineering workshops. Journal of Agriculture \& Social Sciences, pp: 64-65.

10. Kayemuddin M, Kayum S (2013) Problems and prospects of automobile workshops in Bangladesh Journal of African Studies and Development Vol-5.

11. Mukherjee D, Das S (2008) Role of parental education in schooling and child labor decision: Urban India in the last decade. Social Indicators Research 89 : 305-322.

12. Emerson P M, Knabb SD (2006) Opportunity inequality and the intergenerationa transmission of child labor Economica 73: 413-434.

13. Ahmed H (2012) The Impact of Public School Enrolment on Child Labor in Punjab Pakistan. Lahore Journal of Economics 17: 1-34.

14. Siddiqi AF (2013) Important determinants of child labor: A case study for Lahore. American Journal of Economics and Sociology 72: 199-221.

15. Dash BM (2013) Factors contributing the incidence of child labor in small scale commercial establishments: A Study in Delhi OIDA. International Journal of Sustainable Development 5: 41-58.

16. Grootaert C, H Patrinos (2002) A four-country comparative study of child labor Economics of Child Labor Conference, Oslo Noruega, Mayo.

17. Ampomah F (2012) Child Labor in Petty Trading (Hawking Business) in Ghana A Case Study of the Madina and Abokobi areas in the Ga East District.

18. Siddiqi F, HA Patrinos (1995) Child labor: Issues causes and interventions World Bank Washington DC.

19. Nachmias CF, Nachmias D (1992) Research Methods in Social.

20. Ahmad A (2017) Poverty Education and Child Labor in Aligarh City-India Stud Home Com Sci, pp: 165-172.

21. Ali K, Khan REA (2004) Simultaneous Decision-making of Child Schooling and Child Labour in Pakistani Urban Households. Lahore Journal of Economics 9 : 127-148.

22. Boyden J, Ling B, Myers W (1998) What works for working children Rädda barnen, p: 364.

23. Burki A A, Fasih T, Din MU (1998) Households' Non-leisure Time Allocation for Children and Determinants of Child Labour in Punjab Pakistan [with Comments]. The Pakistan Development Review, pp: 899-914.

24. Burki Abid A, Lubna Shahnaz (2001) Implications of household level factors for childern times use in pakistan.

25. Caerwright $K$ (1999) Child labour in Columbia the policy analysis of child labour: A comparative study.

26. Chhetri KK (2011) Child labor in Bhutan: the challenges of implementing child rights in Bhutan. Doctoral dissertation Department of Archaeology and Social Anthrapology, University of Tromoso BT.

27. Devi K, Roy G (2008) Study of child labor among school children in urban and rual areas of Pondicherry. Indian J Community Med 33: 116-118.

28. Dixit P (2004) Road map for NGO's to reduce child labor: what lessons from Indian interventions? Journal of Indian School of Political Economy 16: 234-258.

29. Fronstin P, Greenberg DH, Robins PK (2001) Parental disruption and the labor market performance of children when they reach adulthood. Journal of Population Economics 14: 137-172.

30. Jensen P, Nielsen HS (1997) Child labour or school attendance? Evidence from Zambia. Journal of Population Economics 10: 407-424.

31. Khalid U, L Shahnaz (2004) Socio Economic Conditions of Child Laborers in Pakistan: Evidence from the Labor Force Survey. Lahore Journal of Economics 9: 86-105. 
Citation: Khan MJ, Sadozai KN, Khan K, Khan FM, Khattak MR, et al. (2018) Determinants and Working Conditions of Child Labour: A Case Study of Children Working at Automobiles Workshop at Khyber Pakhtunkhwa (KP), Pakistan. Arts Social Sci J 9: 332. doi: 10.4172/21516200.1000332

Page 7 of 7

32. Khan H (2007) Child labor in Pakistan and other developing countries. The Young Economists Journal 1: 121-132.

33. Patrinos H A, Psacharopoulos G (1997) Family size schooling and child labor in Peru-An empirical analysis. Journal of Population Economics 10: 387-405.

34. Rahman MM, Khanam R (2012) Child labor: the effects of globalisation. The Journal of Applied Business and Economics 13.
35. Ray R (2000) Analysis of child labor in Peru and Pakistan: A comparative study. Journal of Population Economics 13: 3-19.

36. Remington F (1996) Child Labor: A Global Crisis without a Global Response Economic and Political Weekly 31: 3354-3355.

37. Studenmund AH (2001) Using econometrics: A practical guide (4thedn) Boston: Addison-Wesley Longman.

38. Wasserman M ( 2000) Eliminating child labor Regional Review. 